\title{
AN ANALYSIS OF THE WESTERN SCHOLARLY DISCOURSE ON TURKIC IDENTITY IN CENTRAL ASIA
}

\author{
HAYRIYYE KAHVECI
}

\begin{abstract}
The research question is formulated for this study as: Did Western scholarly discourse published in the period between 1950s and 1990s on Turkic identity in Central Asia reflect the Cold War political environment? When there is a rivalry between two states or two groups of states, it can be argued that the study of the other side tends to be biased and created to legitimate the sustainment of the rivalry. When we look at the Cold War political environment, which marked division of international relations into two political poles (East and the West), it is possible to observe this sort of a behavior between those parties as well. This paper relates to this tendency for ideology to affect knowledge. To examine this, the article focuses on the study of Turkic identity in Central Asia by the Western scholars.
\end{abstract}

\section{KEYWORDS}

Discourse; Orientalism; Turkic Identity; Central Asia; Basmac1 Movement; Jadid Movement; Turkic Muslim Congress. 
Since the collapse of the Soviet Union, Central Asia (CA) has been one of the main focuses of recent scholarly investigation. A general geographical definition of the region can be made as it is composed of five former Soviet states Kazakhstan, Kyrgyzstan, Tajikistan, Uzbekistan, and Turkmenistan. Except Tajikistan, the rest are considered Turkic states. Although it is possible to mention the presence of other nationalities, i.e. Russian, the main demographic group of the Turkic states are of Turkish speaking and Muslim. It is very interesting that still today Central Asian states have preserved these two identifying characteristics (Turkishness and Islam) under a colonial administration that was opposed to both religion and nationalism.

The purpose of the article is to provide an analysis of the Western scholarly literature on the Turkic world of CA. If one looks at the initial stage of the birth of Western scholarly studies on Turkic identity, s/he will find that the decade of the 1950s coincided with the initial years of the Cold War as well. Intense geopolitical rivalry between the West and the Soviet Union, the Cold War, took many forms; ideological, economic, political, military. This study relates to the impact of this rivalry on Western scholarship on the Turkic World that was under Soviet domination. A central question to be addressed is whether Cold War discourse is apparent in Western scholarship on the Turkic CA or not.

When there is a rivalry between two states or groups of states, it can be argued that the study of the other side tends to be biased and arguments are based on legitimating the sustainment of the rivalry ${ }^{1}$. When we look at the Cold War political environment, which marked the division of international relations into two political poles (East and the West), it is possible to observe this sort of a behaviour between those two parties as well. ${ }^{2}$ The study relates

\footnotetext{
${ }^{1}$ See, Hans J. Morgenthau, revised by Kenneth W. Thompson, Politics Among Nations, The Struggle For Power and Peace, $6^{\text {th }}$ edition, New York, Alfred A. Knopf, 1985, pp. 31-40.

${ }^{2}$ See also, Ronald E. Powaski, The Cold War, The United States and the Soviet Union, 1917-1991, New York, Oxford, Oxford University Press, 1998; Robert D. Schultzinger, US Diplomacy Since 1900, $4^{\text {th }}$ ed., New York, Oxford, Oxford University Press, 1998.
} 
to this tendency for ideology to affect knowledge. Did the Cold War affect Western scholarship on the Turkic world of CA?

What is knowledge? How it is created and who creates it? Those are important questions that we have to ask to ourselves. How do we acquire knowledge on a particular topic? Do we ask questions or read books? How do we know that it is the truth written in the book? Or what is the truth?

Of course it is not easy to answer these questions. But it is possible to say that knowledge is an important form of power and those who create it or possess it are the actual power holders. This generalization is also correct for history writing. Imagine two countries that are enemies of each other for decades. They have their own history books written from their own perspectives. The same historical events are taught with different presentations.

When we look at the history books written during the Cold War we can see the situation was not that different from our imaginary two enemy countries. On one hand, we can see that each side developed a body of knowledge justifying its own cause. On the other hand, we can see that they have also produced information about the "other" side as well. Creation of knowledge on the "other", as Edward Said argues, makes it easier to define "own-self". ${ }^{3}$ Moreover, creation of perceptions on the weak aspects of the other side even makes it easier to weaken the other side. If we recall the containment strategies of the United States during the Cold War, we would remember the cultural tools, that were used against the Soviet Union. By these cultural tools we mean the production of tremendous amount of movies (i.e. Rambo series) and books about the Soviet Union. Bearing in mind the Western literature on Turkic world of CA, which was mainly stressing the Soviet oppression on nationalities, what would be the answer if one asks the question of whether this literature was created as a result of the Cold War rivalry between East and West? It is hypothesised in this study that the Westem scholarly discourse on Turkic world of CA that came out between the 1950s-1990s is a by-product of the Western containment policies for the East.

\footnotetext{
${ }^{3}$ Edward Said, Orientalism, New York, Vintage Books, 1979, pp. 4-8.
} 
To this end, a group of texts dealing with Turkic world of CA that were written in English in the period from 1950s to 1990s will be examined in terms of how they represent the issue. It has to be noted that the findings of this research are rather exploratory and the observations and conclusions are tentative and open to further research.

\section{What is meant by "Turkic identity" in Central Asia?}

Answer to this question can better be given by looking at the emergence of Turkic identity movements on CA. In order to be able to define what is meant by "Turkic identity" in CA emphasis will be on the initial phase of the identity formation in the region by concentrating on the emergence of the Turkic resistance movements in the Russian Empire. Initially starting as a result of the colonial policies of the tsarist regime, Turkic Moslem resistance movements took different shapes with the Soviet re-conquest. Although there were numerous minor revolts and uprisings, this study will dwell only on some major movements that had significant effect on the shaping of Turkic identity in CA.

The Russian conquest of CA was completed by the last decade of the $19^{\text {th }}$ Century. The end of the conquest meant the beginning of new problems that the empire was to face in a new region. Although the Russian administration did not want to directly change the lifestyles and traditions of the local people, this attitude changed later on. By the end of the $19^{\text {th }}$ century, the region became one of the main pillars of the Russian economy. It was the market and, at the same time, the center of the natural resources. However, day by day increasing numbers of Russian immigrants, together with the question of "surplus lands", lead to an expansion of problems in the Turkistan guberniia. The native people soon felt disturbed on the account of the Russian policies of discrimination favoring the Russian immigrants. Just after the end of the conquest of CA, from 1891-92 the empire was to face the emergence of famine in the region, which contributed to Russian migrations to the newly conquered lands. By the year 1893 the number of Russian immigrants to CA, especially to the Kazak 
steppe climbed to $200,000 .{ }^{4}$ This meant the expropriation of arable lands of the steppe by the Russian Empire.

The Russian expropriation of the arable lands of Turkistan impoverished the local peoples and was accompanied by violence. Day by day, increasing expropriation decisions, together with the increasing number of immigrants, extended the burden on the shoulders of the local Muslim population. They became poorer and poorer. The decisions of expropriation continued even after the First World War.

As a result of discriminatory rule of the Russian Empire, unrest within the region soon erupted into uprisings and revolts. They were not, however, well organized or based on widespread support. In almost all of these revolts the native leaders aimed at the restoration of the former khanates in the region. Most of the leaders were the religious elite of the local people. The first revolt in the Ferghana Valley occurred in 1885 under the leadership of Darwis Khan Tore who declared himself the new Emir of the Khokand Khanate. This attempt was quickly suppressed by the Russian administration. In the "Cholera Revolt" and Andijan Revolt of the following decade Russian authorities were blamed for failing to find solutions to local problems. Nevertheless, all of the later rebellions shared the same fate with the revolt of Darwis Khan Tore; They were crushed down by the Russian authorities as soon as they came out.

The Russian administration showed no willingness to respect and enhance the culture of the local peoples and their reform policies for the region did not take into account the demands of the Muslim population. This was the case too in 1892 when the Russian administration proceeded with a health program, meant to combat cholera in the region. The combat against cholera was carried out in such a way that the treatment of females seemed as threatening the basis of the traditional Muslim society and annoyed conservative feelings. ${ }^{5}$ Since the Russian authorities did not know

\footnotetext{
${ }^{4}$ Micheal Rywkin, Asya'daki Rusya (Russia in Asia), Translated by Behzat Tanc, İstanbul, Boğaziçi Yayınları, 1975, p. 25.

${ }^{5}$ Abdullah Recep Baysun, Türkistan Milli Hareketleri, İstanbul, 1943, p. 6. Helene Carrere d'Encausse, "Systematic Conquest, 1865 to 1884", in Edwars Allworth (ed.), Central Asia, 130 Years of Russian Dominance, A
} 
much about conservative living styles of the indigenous people and the position of women in the society their treatment towards them was not suitable to the lifestyles of the local people.

\section{The Jadid Movement}

The Jadid movement originated from the ideas of Usul Jadid, which refers to the introduction of a new form of education for the Turkic Muslim population living under the Russian Empire. Jadid motto was the achievement of unity in language, action and mind (iște, dilde, fikirde birlik). For decades religious leaders, the mullahs, were responsible for the main educational activity of Muslim CA. This mullah education had nothing to do with the Western scientific method. Their education program was composed only of memorization of some parts of the Qur'an, which made no contribution to the scientific enlightenment of the society. However, it can be said that during the Russian administration, this type of conservative educational system contributed to the preservation of national and religious identity of the people.

This situation of society was disturbing for some of the more educated and enlightened people (aydın) of the Muslim society. It is possible to mention the name of İsmail Bey Gaspiralı (Gasprinsky) as one of these personalities. ${ }^{6} \mathrm{He}$ was a Crimean Tatar who supported the liberalization of Islamic thought and the achievement of national independence. By liberalization of Islamic thought, Gaspiralı was thinking of the achievement of unity in education, language, mind and action among the Muslims of Russia. This process was named as Usul Jadid or Jadidism.

In 1882, Gaspiralı received permission from the Russian administration to publish a newspaper. This was a good opportunity for him to spread his ideas throughout the Muslim population, because the paper was going to be published both in Turkish and Russian. To this end, he started to publish Tercuman

Historical Overview, $3^{\text {rd }}$ ed., Durham and London, Duke University Press, 1994, pp. 165-6.

6Nadir Devlet, Ismail Bey Gaspıralı, Ankara, Başbakanlık Basımevi, 1988. 
(Perevotchik) newspaper in $1883 .^{7}$ There were also some other newspapers, which also published in Turkish in the region. ${ }^{8}$ However, Tercuman was the most important of them.

Publication of newspapers, however, were only one aspect of Jadidism. Gaspiralı and his friends also started to open Usul Jadid schools which thaught the Latin script and new forms of education with scientific method. The first Jadid school was opened in Bahcesaray by Gaspıralı himself. ${ }^{9}$ Similar Jadid schools were opened later on in other cities too. Tercuman was the main tool that was used to give information about these schools and to motivate people to learn this new form of education. It was initially the Tatar merchants who gave their support to the opening of Jadid schools in different parts of Crimea.

Having achieved success in Crimea, Gaspirali turned his attention to Turkistan. In order to be able to spread his reformist ideas in this region, he went to Bukhara in 1893, where he aimed to explain his ideas and open new Jadid schools. However, only by 1900 Munavvar Qari (an Uzbek educated in Turkey) opened the first reformed school in Bukhara only for the young Uzbeks. After this first experiment there were some more reformed schools opened in the Bukhara region. The main aim behind the opening up of the primary schools was to educate young Central Asians using new scientific methods that would prepare the grounds for a society ready for independence.

The autonomy that was given to the Bukharan Emir at the end of the Zirebolak Agreement which put Bukhara under the Russian administration was soon taken away. Although until the Revolution of 1905 unrest remained below the surface, increasing Russian domination in the internal affairs of Bukhara also increased unrest in the region.

${ }^{7}$ Ibid., pp. 23-42.

${ }^{8}$ Those newspapers were Taraqqi (Progress), Khurshid (The Sun), Tujjar (Merchants). For more information on these newspapers see, Helene Carrere d'Encausse, Islam and the Russian Empire, Reform and Revolution in Central Asia, London, I. B. Tauris, 1988, pp. 78-82.

${ }^{9}$ Devlet, Ismail Bey Gasptrall, p. 60. 
The Revolution of 1905 , which mainly emerged from the defeat of Russo-Japanese War, created great tension and internal problems within the Russian Empire; "The defeat was significant not only for Russia, but also for the world; it was the first time for many centuries that a conquering power from the Christian West had collapsed before a non-white people."10 Although the revolution of 1905 was not a Central Asian phenomenon, its impact on CA and the emergence of resistance movements can not be denied. The revolution made Muslim population of the region start to think about the possibility of having national autonomy in the region, thus it contributed to the awakening of the Muslim population.

Jadidism (Usul Jadid), however, was not the only idea within the Muslim population. The emergence of Jadidism divided the Muslim population in the region into two. On the one hand there were conservative Muslims who did not want to see any change, and on the other hand, there were Jadids who wanted to bring reforms. The conservatives rejected the change blaming Gaspirali and his friends for spoiling the religion, and established alliances with the Russian administration in order to crush the activities of the reformist groups. It was also the policy of the Russian administration to bring an end to the Jadid movement. They were in fact aiming to divide the Muslim society, which would have made it easier to rule.

When the Bolshevik unrest began, it appeared that some Jadids were taking the side of the Bolsheviks with the hope of achieving their own national independence. However after a while they realized the aim of the Soviets and joined to another liberation movement; the Basmact. During the first decades of Soviet rule almost all of the Jadid activists were arrested and executed. However this did not bring the end of the resistance movements in Bukhara and more widely in CA. It can be argued that the Russian behavior in the region led to the emergence of stronger movements like the Basmacı movement.

${ }^{10}$ D'Encausse, Islam and the Russian Empire, p. 71. 


\section{The Basmacl Movement (1916)}

Especially after the 1898 Andijan Revolt, the unrest within the Turkic Muslim population towards the Russian Empire continued to increase. Establishment of nationalist groups with short term aims and later on the emergence of Jadid movement were all the reflections of the desires of Turkic Muslim people living in that region. The biggest of the local reactions towards the Russian Empire was the break up of widespread revolt in Fergana Valley in 1916 (the Basmac1 Movement), which can be viewed as the last resistance of the Turkic Muslim population of CA against the Russian Empire.

The role of the Basmaci movement in the Turkistan national struggle was significant. Starting from the last days of the Russian Empire, the Revolt of 1916 and the movement that emerged after played the role of a forum for asserting the demands of the Turkic Muslim society in CA. The name Basmac1, meaning illegal bandits, was given to the people participating in the revolt by the Russian administration. Some scholars argued that this name was given to them in order to crush down the movement even before it started. ${ }^{11}$

The effects of the First World War were reflected in the Russian Empire as in other participants. Quite naturally these tensions were also felt in Turkistan guberniia. The decree of the Russian Tzar, which came out on 8 July 1916 was the seed of the revolt. ${ }^{12} \mathrm{He}$ was ordering the recruitment of Turkic workers from Turkistan to work in the battlefields. Central Asian people regarded this decree as humiliating because they were going to be recruited as servants but not as soldiers of the Russian army. Moreover they did not want to take part in a war waged against Germany, an ally of the Ottoman Empire, their 'ethnic brother'. ${ }^{13}$

All of the above mentioned factors together gave Central Asian Turkic Muslim population the cause to unite and revolt in the Fergana Valley. The revolt started in Tashkent on 11 July

\footnotetext{
${ }^{11}$ Baymirza Hayıt, "Basmacllar" Turkistan Milli Mucadele Tarihi (19171934), Ankara, Türkiye Diyanet Vakfı Yayınları, No. 261, 1997, pp. 1-5. 12Ibid., p. 9

${ }^{13}$ Baysun, Turkistan Milli Hareketleri, p. 18.
} 
1916. It started as a demonstration against the decision of the Tzar, however turned into a bloody revolt. The Russian administration reacted to revolt in a very harsh way. Kropatkin was appointed as the governor of Turkmenistan guberniia, just two days after the revolt began. The main reason behind Kropatkin's appointment was the belief that he was the only person who knew the people of the region well enough o combat. In fact, Kropatkin and his forces immediately crushed the revolt. Many people were arrested and killed without trial. Despite the harsh end of the 1916 revolt, this was just the beginning of the Basmaci movement which was to continue until the mid-1930s.

It is also known that Enver Pasha, former minister of war and acting commander in chief of the Ottoman Empire on the eve of the First World War, had actively participated in the Basmac1 movement as well. He was first brought to Russia by Soviet initiative in order to play a mediator role between Central Asians and the Soviet government. However, he then turned to take the leadership role of the movement, organized armed-struggle against Soviet oppression in the region, where he died in one of the armed attacks in 1922. It was thought by the Soviet administrators of the time that his death would bring the end of the Basmaci movement which was facing problems on the new leadership. Nevertheless, this was not the case and the movement continued until mid1930s. ${ }^{14}$

Turkic Muslim Congreses in the Russian Empire (19051917)

Mainly as a result of the Russian Revolution of 1905 Turkic Muslim population too was looking for possibilities to increase their voices and to find solutions to their problems. Although they did not participate in the 1905 Revolution, it made them to unite and to think of collective solutions to their problems. As a result of this search, the Muslim congresses of the pre-Bolshevik revolution era re-emerged. These congresses carry importance in the national awakening of the Turkic Muslim society living under Russian hegemony. Before the Bolshevik Revolution of 1917, three Muslim congresses were held in Russia. They were respectively held in the

${ }^{14}$ Hayit, Basmacllar, p. 320. 
years of 1905,1906 and 1914 . It is worth to mention these congress in order to understand the emergence of further actions of Turkic Muslim society in CA.

It was inevitable for the Turkic Muslim population of CA to be effected by the influences of the ongoing reactionary movements which especially mushroomed as a result of the growing economic depression at the end of the Russo-Japanese War of 1904-1905.15 Group movements and riots that were mushrooming in almost every part of the Russian Empire started to give signals of mass, strongly organized civil movements against the Tsarist administration. Frightened from the possibility of a mass reaction in 17 September 1905, Tsar Nicolai II had to accept the "Manifesto" provided by the Russian civil organizations.

In general, the essence of the "Manifesto" was consisted of the accordance of basic rights and freedoms to the Russian people; "By this manifesto the emperor granted the Russian nation: 1) the fundamental principles of civil liberty - inviolability of person, and freedom of thought, speech, assembly, and organization; 2) democratic francise; 3) no law to be henceforth without the consent of the Duma."16 Acceptance of these basic rights and freedoms led to the emergence of a "freedom" environment in the Russian Empire. The effects of these reformist movements were soon felt among the Central Asian Muslim population as well.

Almost all of the movements that came out in CA before 1905 were not mature and they were lacking in organization. It was noted by Hablemitoğlu that the main important pre-1905 Turkic Muslim event in CA was the anniversary celebrations of the Tercuman newspaper. He also mentioned that the $10^{\text {th }}$ and $20^{\text {th }}$ celebrations of Tercuman in 1893 and 1903 respectively were the biggest organizations of the time. There was no Russian opposition to these celebrations because they did not have any political character.

${ }^{15}$ For more information see, Bernard Pares, History of Russia, New York, Vintage Books, 1965, pp. 447-66.

${ }^{16}$ George Vernadsky, A History of Russia, $4^{\text {th }}$ edition, New Heaven, Yale University Press, 1954, p. 266. 
The outbreak of the Revolution of 1905 had a positive effect on the organization of further meetings with the hope of reform in 'land, property and religious independence' issues. These groups were mainly formed by intellectuals that were increasingly composed of number of Jadids and the audience of Tercuman. Moreover, increasing communication among Central Asian people, mainly through widespread railway network, can be mentioned as other contributing factor to the awakening of local people, and pawed the way for organization of Turkic Muslim Congresses and institutions.

Revolutionary sentiments in the first half of 1905 were felt among Turkic Muslim population of Russia as well. In fact it can be said that pre-Revolutionary economic depression were felt among non-Russian population more than the Russians. The reason behind this was the discriminatory treatment of the Tsarist regime towards the Russian and non-Russians. The first congress of Turkic Muslim population was held with the aim of elimination of these inequalities. As a matter of fact, before the organization of the First Congress (August 15, 1905), several petitions were submitted to the Tsarist administration from different Muslim parts of the Russian Empire. Nevertheless none of these petitions got a response. Organization of a wider based event like a congress of Turks from all around the Empire was expected to mobilize the Turkic Muslim population and bring their affairs to the attention of the administration.

It was decided that all of the representatives will meet in the Mekerce Fair at Nijni Novgorod. ${ }^{17}$ In order to be able to held the first congress, İsmail Gapıralı, Abdurreşid Ibrahimov and other leaders of the Turkic Muslim society asked permission for gathering from the Nijni Novgorod administration. Their request was rejected and this forced them to held the meting secretly. For security reasons, they decided to held the meeting in a ship floating on the river. A trip appearance was given to the gathering. Participants came to Gustav Struve ship as coming to a ship trip on the Oka River. ${ }^{18}$ The decisions of the first congress were aimed for

\footnotetext{
${ }^{17}$ Necip Hablemitoğlu, Çarlık Rusyasinda Türk Kongreleri, 1905-1917 (Turkic Congresses in Tsarist Russia, 1905-1917), Ankara, Ankara Üniversitesi Basımevi, 1997, p. 53.

${ }^{18}$ Ibid., pp. 53-54.
} 
the establishment of an organization that would unite all Turks of Russia. This was seen as the vital precondition for the achievement of their basic rights and freedoms.

It is possible to summarize the decisions of the first congress under five topics: 1) The conditions of the Empire necessitates the union of all Muslims in social, cultural and political action; 2) Taking action with the Russian reformists for achievement of legal conditions for equal representation; 3) For the achievement of their aims it was decided to use all necessary means; 4) Education was one of the essentials for the future of the Turkic Muslim society. For this end, vitality of opening schools, reading rooms, publishing journals and books was stressed; 5) The establishment of sixteen local majlises that would work for the achievement of the above mentioned aims and organization of further Muslim congresses. ${ }^{19}$

The political environment in the Russian Empire after the acceptance of Manifesto of September $30^{\text {th }}$ raised the hopes of Turkic Muslim population. The developments in the Empire made them to look for the organization of a Second Congress (January 13-23, 1906) that would clarify the position of Ittifak. The initial preparatory announcements of the second congress came out as newpaper articles in Ulfet and Tercuman. In their articles, Abdurresid Ibrahim and Ismail Gaspiralı were trying to show the society how vital it is to have the second congress organized.

Even starting from November, Gaspiralı was pointing out his ideas about the agenda of the second congress through his articles: 1) deciding the administrative style of the Rusya Müslümanlar Ittifakl (The Union of the Muslims of Russia); ${ }^{20}$ 2) deciding the selection of the Russian political party that they are going to cooperate; 3) Discussing the ways how the number of Turks in Duma can be increased; 4) protection of lands of Turks; 5) elimination of laws that put barriers in front of the rights of Turks;

\footnotetext{
${ }^{19}$ Devlet, Ismail Bey Gaspıralt, pp. 80-81.

${ }^{20}$ In fact in September 1905 the charter and program of "Ittifak" was formulated by Ali Merdan Topşubaşı, Ahmet Aga(ev) and Abrurreşid Ibrahim, in order to find ways to stop Armenian attacks on Turks in Caucasia and Azerbaijan. Baku majlis declared the temporary center of "Ittifak"; however it is possible to say that they have not been successful. See Hablemitoğlu, Çarlık Rusyası'nda Türk Kongreleri, p. 56.
} 
6) according Kirgiz and unsettled populations the right to become included into religious centers; 7)giving the opportunity to the people who were pushed to choose Christianity to be able to choose their religion; 8 ) accordance of the same rights to Muslim religious men as accorded to the Russian religious men; 9) opening of schools suitable to the standards of modern life; 10) opening teacher schools; 11) appointing qualified people as the heads of religious centres. ${ }^{21}$

During the formation days of the Ittifak, the establishment of political parties was illegal in the Russian Empire. However, after the Manifesto of September 30 and the post 1905 revolution, Empire faced the establishment of various political parties. In order to provide the opportunity to the Turkic Muslim population to be represented in the Duma, it was necessary to organize Ittifak as a political party. Nevertheless, time was not enough for the participation of Ittifak as a political party in the Duma elections. Existing political setting required the organization of Second Congress of Turkic Muslim population of Russia.

The duty of the organization of the Second Congress was given to the Kazan Majlis. Yusuf Akcura, who was the leading activist of the Kazan Majlis, started the preparation of the second congress, that was declared to be held in $15^{\text {th }}$ of January 1906 at St. Petersburg. He also informed other majlises and asked for the permission from the administration for this sort of a gathering. However, it was not possible to receive a positive answer. Until January $22^{\text {nd }}$ representatives who came to St. Petersburg were coming together informally and trying to find out a possible solution to the permission problem. On January $22^{\text {nd }}$, St. Petersburg newspapers declared that "all kind of meetings are permitted" by the administration. Consequently in January $23^{\text {rd }}$, with the participation of more than fifty representatives, Second Congress was held in the house of one of the participants, Muhammed Alim Maksud in St. Petersburg. 22 The Second Congress marked the establishment of the political party called the Rusya Müslümanlarl İttifakı (The Union of Muslims of Russia), ${ }^{23}$

${ }^{21}$ Ibid., p. 58.

${ }^{22}$ Devlet, Ismail Bey Gaspirall, p. 84.

${ }^{23}$ For the party charter and the program see; Hablemitoğlu, Çarlık Rusyasinda Türk Kongreleri , pp. 59-68. 
although it was not yet legally accepted and could not participate in the first Duma elections.

The main outcome of the Second Congress was the decision regarding the participation of the Central Asian Turkic Muslim population in the Duma elections. Since the position of the Union was not legal yet, it was decided at the end of the congress to participate in Duma elections on the side of the Russian Kadet Party (the Constitutional Democrats).

As it was decided at the end of the Second Congress, Rusya Müslümanları Ittifakl participated in the first Duma elections in cooperation with the Kadet Party. Thirty six members of the Union of the Muslims of Russia were elected for the Duma. However the first Duma did not had a long life. Just after few months from its first meeting, it was dissolved with the order of Tsar Nicolai II.

The idea of the organization of the Third Congress (August $16-21,1906)$ was decided in the previous gathering, and the duty to get permission, was given to the Muslim members of the Duma. Naturally, this was not an easy task for them. For this they have done several unsuccessful attempts. In the end, the final application, which was prepared very conservatively and proRussian, managed to receive a positive response. However, the conservative content of the application disturbed the liberal feelings of some activists like İsmail Gapıralı. The proposal that was submitted to the administration for the Third Congress did not have any political agenda and this was the main point that received reaction and created division among the members of the union. It was just composed of the cultural and religious affairs of the Turkic Muslim population. Nevertheless, this was the only way to get permission from the administration.

In order to eliminate the divisions, Abdurreşid Ibrahim(ov), a member of the Duma, made a declaration at the beginning of the congress mentioning that the conservative aspects were used in the proposal only for the security and the legal purposes and he himself was also for the discussion of the political issues. This announcement helped to eliminate the internal tension and division. 
The Third Congress, like the First Congress, took place in Nijni Novgorod during the Mekerce Fair. It resulted with the acceptance of the declaration of Union as a political party with its charter and program decided in the Second Congress. ${ }^{24}$ The first day of the congress ended with the establishment of two commissions, namely the "commission of education" and the "commission of religion". Each of the commissions was formed of fifteen members with the responsibility of preparing reports concerning educational and religious needs of the Turkic Muslim society. The conference ended with the discussion and acceptance of these reports prepared by the two commissions. 25

The main outcome of the Third Congress was the decision regarding the decleration of Union of Muslims of Russia as a political party. For this end Central Administrative Committee of the Union made a legal application to the Tsarist administration for the establishment of the party on legal bases. However this application was rejected. This was an attempt by the Tsarist administration to prevent increasing Muslim representation in Duma.

Abolition of the second Duma with its thirty-nine Muslim members, increasing discriminatory policies of the Tsarist administration against the Muslim population in the third Duma elections, and harsh attacks on Jadids and Jadid schools almost erased the unionist attempts of the Turkic Muslim population of CA till the Bolshkevik Revolution. ${ }^{26}$

Organization of the Fourth Congress was not easy in the post Third Congress environment. It took seven years after the third congress to establish the fourth one. Dissolution of the second Duma and the worsening conditions in the Empire made it impossible to get permission for the fourth congress. These conditions made most of the activists like Yusuf Akçura and Abrurreşid Ibrahimov to leave the country.

The permission for the organization of the Fourth Congress of Turkic Muslim population of Russia could only be requested by

\footnotetext{
${ }^{24}$ Ibid., p. 74.

${ }^{25}$ Ibid., pp. 74-79.

${ }^{26}$ For more information see, ibid., p. 85.
} 
the few Muslim members of the Duma. They had been able to get the permission for the fourth congress to be held on $25^{\text {th }}$ of June 1914 in St. Petersburg. The congress was announced through the Turkic Muslim newspapers in the Empire.

Hablemitoğlu argues that it was not just a coincidence for the Tsarist administration to give permission to the fourth congress just before the outbreak of the First World War. According to him the mere aim behind the permission for the Fourth Congress was to learn the position of Muslim population, and also to gain popularity in their eyes, bearing in mind the coming war.

It is not possible to accept the effects of the Fourth Congress same as previous three. It can be characterized as a forum in which religious and cultural affairs were discussed and demands requested from the empire which received no response. The Fourth Congress had almost no influence on the political struggle of the Turkic Muslim population. Worsening conditions in the Empire soon break out in CA in the form of a revolt in 1916 as previously mentioned.

When the Russian Empire was facing the February Revolution in 1917, what was this wind of change was promising for the Central Asian people? Although they did not actively participated in the revolution it was inevitable for them not to get influenced from the ongoing change. Initially, February revolution and later on the Bolshevik Revolution gave a hope of independence to the hearts of Central Asians. Being subject to oppression by the Russian Empire and also by their local feudal leaders was disturbing Central Asian liberal elite.

One has to remember that since the Russian conquest of CA local people were showing their opposition towards oppression with the resistance movements. However liberal elite of CA was aware of the fact that it was not possible for them to achieve their ethnic selfdetermination all alone. Because in addition to the forces of the Empire, on the local level, they had to fight with the khan or emir and the conservative group around them. In order to achieve independence and to avoide oppression, they knew that they had to get help from outside. 
In the February Revolution, it is possible to say that there is not any Central Asian input. Almost everything planned and acted in Petersburg. But the news and influences of the revolution gave Central Asian liberal elite (Jadids) an opportunity to look for help from the Provisional Government for the overthrow of the local monarchies and the establishment of new reformed states in the region. Furthermore, Bolshevik slogans find a popular appeal in the region because it was promising Central Asian population the right for self-determination.

Although the result was not the achievement of national independence in the region. The promises of the Bolsheviks, even though misleading, was something that they were looking for a long time.

\section{What the analysis of Western scholarly discourse on "Turkic Identity" tells us?}

Analyzing the contents of texts on a particular subject can help us to understand the relationship between knowledge and power. Creation of knowledge about international relations becomes a tool of the international political order. ${ }^{27}$ For example reading Edward Said's Orientalism and thinking about the historical political conditions of the colonial period, we can understand the devastating literature created about the Orient for the sake of establishing solid legitimacy in the colonized parts of the world. ${ }^{28}$ Furthermore, this trend continued even after the end of the colonial rule when new forms of colonial relations were established between the core and the periphery states.

For the purposes of this article the concentration is made on the existing literature in English on "Turkic identity" in CA during and after the Cold War. As previously mentioned it was

${ }^{27}$ Said's definition of pure and political knowledge: "It is very easy to argue that knowledge about Shakespeare or Wordsworth is not political whereas knowledge about contemporary China or the Soviet Union is". See Said, Orientalism, p. 9.

${ }^{28}$ Where Said himself defines the Orientalism as a "...style of thought based upon an ontological and epistemological distinction made between "the Orient" and (most of the time) "the Occident". Ibid., p. 2. 
hypothesised that the literature during the Cold War was a part of "Big Power political discourse" which came into existence with the end of the Second World War. It is possible to define this "Big Power political discourse" as whole body of literature on the two main poles of the period, that is the Soviet Union and the United States of America. This international political discourse has two dimensions. The first one consisted of the books, articles, movies and many other instruments prepared in the west about the east and the second one is the reverse, that is all the information prepared in the east about the west.

This article concentrates is on the first dimension of the "Big Power Political discourse". Specifically, it will focus on the academic discourse on Turkic identity in CA. The analysis is made under four groups which is based on the division of the material. First group will consists of the literature written during the Cold War on the Tsarist administration. Group two will consists of the literature written during the Cold War on the Soviet administration. Group three will consists of the literature written after the Cold War on the Tsarist administration and lastly the group four will be on the analysis of the same particular literature on the Soviet administration.

\section{The Cold War Literature on the Turkic Identity under the Tsarist Administration: Group 1}

The rationale for analysing tsarist regime and the presentation of the position of Turkic identity in the discourse written during the Cold War is to provide a criterion for the comparison with that of the Soviet regime. The aim is to show how the position of writers changed on a particular topic depending on the international political conditions. The presentation of the Russian conquest and its influences on the local people in the Western literature will be studied. Considering the fact that initial responses that came out against the Russian policies were the seeds of development of an identity in the region, this section will provide the first step to go further in the analysis of the issue of Turkic identity in the region. For the purposes of this section analysis will be done through a sample of texts that is grouped according to their publication dates and the historical time spans that they are dealing with. 
As a late coloniser country when the Russian Empire was moving towards $\mathrm{CA}$, their main justification for their move was the immediate need to take security precautions. Inconsistent relations between Central Asian Khanates made this process even easier for the Russian Empire to go on and achieve its goals. For the tsarist regime people of the region were uncivilised nomads and in need for some power above them to rule and protect their lives. However, one can not deny the fact that this justification is not much more different from the justifications of other colonizer countries.

Reading the following passage from Helene Carrere d'Encausse who is one of the respected scholars of CA in the West will give us hints about how the Russian conquest was justified by her words while she was explaining the conquest of the Emirate of Bukhara:

The Crimean War temporarily restricted Russia's relations with the emirate; but once the war was over, Russia was free to turn anew towards Asia, where external threats were taking clear shape. Having consolidated its position in India, Britain was extending its presence in Afghanistan, and British envoys were multiplying in the Central Asian khanates. Meanwhile, the Afghan ruler Dust Muhammad had just taken Balkh and was extending his control over the entire region to the south of the Amu Darya. It became urgent for the Russian government to re-establish friendly links with the rulers of Central Asia, primarily with Bukhara, which was the object of the strongest Anglo-Afghan pressure. ${ }^{29}$

In the above lines we can see that the stress is on the need for "urgent" security precautions for the sake of the Russian Empire. Nevertheless, it is interesting to note that if we want to look at the position of the international agenda during those years of the Russian conquest of CA, we can see that there is a widespread tendency in the industrialised countries of the time to conquer less developed places and maintain resources as well as markets for their industrial production. Above mentioned Crimean War (185356), was the last move of the Russian imperialism towards Middle East which was crushed down by the Ottoman Empire with British

${ }^{29}$ D'Encausse, Islam and the Russian Empire, p. 37. 
and French support. This leads us to question the mere political reasons given for the conquest of the region.

The conquest of CA by the Russian Empire meant initial Russian encounter with Islam. When we look at its definition of Islam before the Russian conquest of Bukhara, we can get a clear idea on how important is the role of Islam in the lives of Central Asian people as a whole.

Over and above men and the regime, Islam furnished a meeting-place and a catalyst for all the forces that were either shaking or immobilising the emirate. There are few Islamic countries in which during the $19^{\text {th }}$ century the role of religion was so fundamental; for it was simultaneously the basis of the state and the only force that stood apart from the emir's power and might possibly serve as a counterweight to him - a force that transcended all others and participated, at all levels, in the life of both rulers and masses. ${ }^{30}$

Since Islam was playing a crucial role in Central Asia, any attempt by the Russian rule to change any aspect of Islam meant an attack to the identity of the local people. As soon as the protectorates established as a result of the Russian conquest, tsarist administration started to take some measures about the lives of people. As described above, Islam plays the major role in their daily lives. This explains the reason for usage of the Arabic script as the main medium of written communication in the region. All over CA, Arabic script was used as the common binding factor in the lives of the local people. It was a medium of communication that was totally different from that of the new masters of the region.

While defining the culture of Central Asian peoples in her book Central Asians Under Russian Rule: A Study in Culture Change, Elizabeth Bacon was arguing that: "The Arabic script was thus something all the Central Asian peoples had in common, both as a familiar system of writing and as a symbol of religious and cultural ties with the larger Islamic world. A few scattered attempts

${ }^{30}$ Ibid., p. 31. 
to introduce the Cyrillic alphabet in the nineteenth century had been ineffective". 31

From her words, the reader gets the impression that there was not any serious attempt by the tsarist regime to alter the lifestyles of the local people although there were "few scattered" moves to change the Arabic script with the Cyrillic alphabet! The importance of her word on the tsarist regime becomes much more significant when we look what she wrote about the Soviet attempts to change the local alphabet with more or less similar aims with the tsarist regime: "... to a Soviet Government that had had to establish its control over Central Asia by force, the dangers soon became obvious of allowing its people to continue to use of an alphabet that at once separated them from Russians and gave them a common mode of expression with Moslem neighbours outside the Soviet Union. In 1925 the importation of materials was forbidden by decree". 32

The issue of alphabet and the attempts to change it becomes much more important if we think of the very fact that language plays an important role in the identification of people themselves with a particular group. From Bacon's words we can see that there is a stress on the Soviet rather than the tsarist policies to change the indigenous alphabet.

Moreover, as a result of the Russian colonial policy day by day the number of Russian settlers were increasing in the region and local people were pushed to share their land with their new neighbours. ${ }^{33}$ Disharmony of the two societies in the region was

${ }^{31}$ Elizabeth E. Bacon, Central Asians Under Russian Rule: A Study in Culture Change, New York, Cornell University Press, 1980, p. 190. 32Ibid.

33"By 1912 more than 1,5 million Russians made up 40 percent of the population of the Kazakh steppes. In a continuing cycle, the ever-growing Russian population forced the Kazakhs into smaller spaces and the contradiction of the Kazakhs encouraged still further Russian colonization. From the Russian point of view, colonization made it possible to convert the fertile steppe region from pastoral to agricultural uses, to secure against possible revolts, and to reduce population pressure in western and central Russia. From the Kazakh point of view it meant the destruction of their society. The Kazakhs were forced into daily conflict with Russian settlers and were deprived of their migration routes, water, and land". See 
one of the main sources for the emergence of local revolts in CA, which were the founding steps of the development of Turkic identity in the region. Nevertheless, while being one of the main sources of the birth of conflict in this part of the world, Russian settlers were viewed as the modernisers of the region. When we look at Seymor Becker's writing in Russian Protectorates in Central Asia: Bukhara and Khiva, 1865-1924, he argued in 1968 that "The most important channel of Western influence in Bukhara was the Russians, who arrived in increasing numbers after 1885 , either as soldiers to operate the railway, garrison the cantonments, and guard the Amu-Darya frontier, as merchants, shopkeepers, and workers." ${ }^{34} \mathrm{We}$ can see that he was not following a much less different pattern from that of the Orientalist writers who were presenting the colonisers as gifts of mercy to the colonised people.

When we look at the presentation of the Jadid Movement, which is one of the milestones that played an important role in the development of Turkic identity in the region, we can see that it is presented as a mere educational movement. The aims of the Bukharan liberals admitedly remained essentially educational, but in a broader sense than before. They set themselves the task not only of eliminating illiteracy and ignorance in the khanate but also of educating the people to an awareness of the uselessness and the reactionary role of the clergy, of government arbitrariness and illegality, and of the emir's appropriation for his own use of state revenues that ought properly to be spent on the needs of the country. ${ }^{35}$

When we recall the motto of Jadid Movement that was developed by İsmail Gapıralı, "dilde, işte, fikirde birlik" (unity in language, action and mind), we can see that it propagates the establishment of a unity of Turkic people. This unity aims at the development of a monotype language for all Turks of Russia,

Ira M. Lapidus, A History of Islamic Societies, New York, Cambridge University Press, 1991, p. 787.

${ }^{34}$ Seymour Becker, Russian Protectorates in Central Asia: Bukhara and Khiva, 1865-1924, Cambridge, Masachussets, Harvard University Press, 1968, p. 193.

35Ibid., p. 205. 
which will be followed by the monotype action and ideology (mind). Jadid slogan had a much broader meaning than educational as Becker stressed it. However, the significance of Jadidism as a political factor in the development of Turkic identity was a fact not only of CA but of the Ottoman Empire as well. It is clear that the Jadids who fled to Istanbul had influenced the emergence and participated in the 1908 Young Turk Revolution, which was the generator of Turkish nationalism in the Ottoman Empire. ${ }^{36}$

In sum it is possible to say that regarding the Turkic identity in CA under tsarist regime, there is not much information provided by the writers of the Cold War period. The Russian conquests were represented as a slight process and their role vis-d-vis the local population were represented as the modernisers who brought civilisation. Moreover, the blame for the worsening condition of the local peoples was placed on the local leaders, who were mainly represented as concerned only for their own well-being.

\section{Cold War Literature on Turkic Identity under Soviet Regime: Group 2}

As discussed in the previous section, the issue of Turkic identity under Tsarist regime was somehow skipped over quickly in the western texts and the concentration was given on the Soviet regime and its policies. It seems that the main reason behind this was the ongoing Cold War environment, which had its reflections on the academic works as well. The almost unnoticed position of Turkic identity under Tsarist rule gained a rapprochement when the discourse focuses on the Soviet administration. The concentration of this section will be on the presentation of the revolutionary environment of 1917 and the position of Turkic identity in the aftermath of the Bolshevik Revolution.

\footnotetext{
${ }^{36}$ Sevket Süreyya Aydemir, Makedonya'dan Ortaasya'ya Enver Paşa, Cilt 2: 1908-1914 (Enver Pasha, from Macedonia to Central Asia, Vol. II), İstanbul, Yükselen Matbaacılık, 1971, pp. 448-473.
} 
The promises of the revolution, in general, were filled with the concepts of freedom, equality and self-determination. ${ }^{37}$ 'What did those concepts mean for Central Asians?' is a significant question to ask. In her book Islam and the Russian Empire (1988), Helene Carrere d'Encausse presented an overview of the meaning of the revolution both for Russians and indigenous Central Asians:

For the Russians, the revolution meant bread and individual freedom; for the locals, it implied bread, but above all independence. This difference of viewpoint, which appeared clearly from the summer of 1917 on, merely grew sharper thereafter. In the Bolshevik Revolution, the indigenous population placed their sole hope in the revolution keeping its promises to the oppressed nations when the party was in opposition. ${ }^{38}$

D'Encausse stressed the "promised independence" for Central Asians. It seems that by stressing the promised character of independence for Central Asians, she is trying to show that this promise was never operationalized under the Soviet regime. Her intention of assaulting the Soviet rule becomes much more clear when we read her words on the national delimitation policy of the early 1920 s which is pursued by the Soviet regime:

${ }^{37}$ For further information see: J. V. Stalin, "Marxism and the National Question", in J. V. Stalin, Works, Vol. 2, Moscow, Foreign Languages Publishing House, 1954, pp. 300-381 at [http://www.gate.cruzio.com/ marx2mao/Stalin/MNQ12.html]; J. V. Stalin, "Concerning the Presentation of the National Question", in J. V. Stalin, Works, Vol. 5, Moscow, Foreign Languages Publishing House, 1953 , pp. $52-60$ at [http://www.gate.cruzio.com/ marx2mao/Stalin/ CPNQ21.html]; V. I. Lenin, "The National Question in Our Programme", in V. I. Lenin, Collected Works, $4^{\text {th }}$ ed., Moscow, Progress Publishers, 1964, Vol. 6, pp. 454-463 at [http://www.gate.cruzio.com/ marx2mao/ Lenin/NQP03.html]; V. I. Lenin, "The Right of Nations to Self determination", in V. I. Lenin, Collected Works, $4^{\text {th }}$ ed., Moscow, Progress Publishers, 1964, Vol. 20, pp. 393-454 at [http://www.gate.cruzio.com/ marx2mao/Lenin/RNSD14.html]; V. I. Lenin, "The Socialist Revolution and the Right of Nations to Self Determination (Thesis)", in V. I. Lenin, Collected Works, $4^{\text {th }}$ edition, Moscow, Progress Publishers, 1964, Vol. 22, pp. 143-56, at [http://www.gate.cruzio.com/ marx2mao/Lenin/SRSD16.html].

${ }^{38}$ D'Encausse, Islam and the Russian Empire, pp. 149-159. 
With its reorganization of Central Asia the Soviet government delivered a terrible blow to the pan-Turk[ic] dreams of the Jadids. The fragmentation of Turkistan into national republics endowed with national languages and, worse still, the creation of a non-Turkish republic of Tajikistan, in which a Persian dialect was spoken, put an end to any hope of a regroupment and unification of all the Turks of Central Asia. As early as 1923, ... the existence of a region called 'Turkistan' was impossible, since it was the most blatant demonstration of a 'Great Turkish aspiration which should be erased from the Soviet terminology as soon as possible'. ${ }^{39}$

The above lines provide a clear demonstration of the Cold War attitude towards the Soviet Union. It seems that with stressing the negative Soviet attitudes by using words like 'terrible blow', d'Encausse is trying to awaken Turkic nationalism in the region by presenting the Soviet regime and its policies as the mere obstacle in front of the establishment of a unified Turkistan and the development of a unified Turkic identity in CA.

A similar pattern to that of d'Encausse can be observed when we look at the part dealing with CA in Walter Kolarz's book called Russia and Her Colonies. Like d'Encausse, Kolarz too stressed the negative effect of the delimitation policies on Central Asian identity building. Moreover, he has a special stress on the effects of these policies on Turkic identity as well.

By dividing Soviet Central Asia into five national republics the Government of the Soviet Union not only served the aims of its foreign policy but also safeguarded the stability of Russian rule in Soviet Central Asia itself. With the exception of the Tadzhiks [Tajicks] and some minor ethnical groups, the nationalities of Soviet Central Asia are all Turkic peoples intimately inter-related. The formation of a Central Asiatic federation would, therefore, be quite logical and would probably correspond to the desires of the peoples concerned. Such a federation is, however, bound to threaten Russian predominance and weaken the links between the Central Asian power and each of five Central Asiatic Republics. The Soviet central government has, therefore, strongly opposed all federative tendencies. ${ }^{40}$

\footnotetext{
${ }^{39}$ Ibid., p. 184

${ }^{40}$ Walter Kolarz, Russia and Her Colonies, New York, Praeger, 1952, pp. $259-60$.
} 
Kolarz stresses with his above words the fact that Soviet policies in the region had no respect for the demands of the local people, but the mere reason for the formation of these policies was to safeguard the interests of the regime. If we recall the promises of the revolution for the local Central Asians and look again to the words of Kolarz which stresses that a possible Central Asiatic federation is a major threat to the Soviet integrity; it seems that by stressing the fact that the majority of Central Asian population is Turkic and they were oppressed by the Soviet regime, he was in effect, if not by intention, focusing attention on this very fact in the scholarly discourse on CA.

On the other hand, while defining Islam's role in CA, Micheal Rywkin, Moscow's Muslim Challenge; Soviet Central Asia (1990), was using the following words:

Islam is not only a religion but a part of personal identity: one can not simply call oneself an Uzbek or a Tajik and, at the same time, reject Islam. This not only strengthens the Islamic tradition but makes it part and parcel of the ethnic one. And ethnic traditions, even apparently much weaker ones, are highly resistant to change or erosion. ${ }^{41}$

In his last sentence there is a stress on the strength and resistance of ethnic traditions to the external influences. Looking at his first sentences which is on the Uzbek, Tajik or other identities that was created by the Soviet delimitation policies, it can be seen that he is rejecting the actual existence of this artificially created identities for the Turkic and non-Turkic peoples of CA. Moreover, when we look at his words on the current - that is the very ends of the 1980s - position of Islam in the region it can be seen that he views Islam as a great danger to Moscow's control over CA.

Rapid modernization (education, urbanization, technical progress, etc.), however, has not brought with it the acculturation desired by the Soviets. An educated Uzbek manager and party member may speak Russian, ride to work in an automobile, and dress in Western style; but this has no bearing on his national-religious feelings. On the contrary "his" Islam is even more dangerous to Moscow. It is not a faith of "superstitions" or of perezhitki (survivals from the past),

\footnotetext{
${ }^{41}$ Micheal Rywkin, Moscow's Muslim Challenge; Soviet Central Asia, revised edition, New York, M. E. Sharpe Inc., 1990, p. 89.
} 
something a skillful agitator might at least try to demolish at the next public meeting. Rather, it is the basis of his national-religious identity and consciousness. (...) Of the two dogmas, the communist and the Islamic - both collectivist and authoritarian, both encompassing the temporal as well as the spiritual, both competing for the Soviet Muslim's allegiance - the communist one, being a Russian import, appears to be the weaker. In the nationalist-Muslimcommunist triad, therefore, the communist element seems the only one potentially discardable. ${ }^{42}$

On the other hand, when we look at the presentation of the Basmaci movement we can see that there is not common agreement on the date of the emergence of the movement. While d'Encausse argues that the movement started as early 1920s, Rywkin was giving the date of 1918 which is right after the Bolshevik Revolution. However, as previously mentioned, the actual roots of the Basmaci movement goes back to the Central Asian revolt of 1916 in the Fergana Valley. ${ }^{43}$ This means that the birth of the movement was before the Soviet regime. However, it is interesting to note that the Cold War writers tend to give stress to the aftermath of the Bolshevik Revolution. This kind of an attitude can be given as a justification of an hypothesis on the impact of the Cold War rivalry on the creation of a body of knowledge on the Turkic identity in CA. Micheal Rywkin defines the Basmacı movement as:

...the Basmachi movement was a national-liberation movement on par with the many similar ones that have emerged in Asia and Africa since the end of the World War II. It is worth noting that the descendents of the Basmachi who took refuge in Afghanistan in the 1920s were in the forefront in the guerilla battle against the Soviet troops "pacifying" Afghanistan - sixty years later, with greater success this time. ${ }^{44}$

While stressing the national liberation movement character of the Basmaci movement, the author also emphasized the post-World War II environment. The end of World War II meant the end of colonial rule in most parts of the world - as mentioned by Rywkin in Asia and Africa too. The world faced the establishment of numerous new independent states in the second half of the $20^{\text {th }}$

\footnotetext{
42 Ibid., p. 91

${ }^{43}$ Also see Hayit, Basmacular.

${ }^{44}$ D'Encausse, Islam and the Russian Empire, p. 43.
} 
century but CA still remained under colonial control. His stress on Afghanistan and the success of Afghan masses, with the "descendants of the Basmachi who took refuge ... in the 1920s" can be given as another important aspect of Cold War rivalry.

\section{Post-Cold War Literature on Turkish National Identity under Tsarist Regime: Group 3}

The fall of the Berlin Wall and the collapse of the Soviet Union were two milestones of the $20^{\text {th }}$ century that marked the end of the Cold War. This meant the end of an era of bi-polar rivalry between the East and the West. According to some, it was the beginning of a new world order. Was it a real new international order or was it the continuation of old order with modifications to suit the new conditions? In this section we will try to find an answer to this question from the point of the position of the existing literature on the Turkic identity in Central Asia.

In 1994, Edward Allworth published the third edition of his edited book Central Asia: A Century of Russian Rule, which was first published in 1967. This the time book's name was Central Asia, 130 Years of Russian Dominance: A Historical Overview. First book was published during the Cold War. However, it is interesting to observe that although the Cold War period ended for three years when the third edition of the book came out in 1994, the words 'Russian rule' changed with much more stronger words of 'Russian dominance'. Even this small alteration in the title of Alworth's book can give us hints regarding the post-Cold War attitudes of the writers. It seems that although the Cold War and the rivalry between the East and the West ended, the old dogmas continued in the new era.

Just six years after the publication of her book Islam and the Russian Empire; Reform and Revolution in Central Asia, ${ }^{45}$ where d'Encausse was stressing the political factors which lie behind the Russian conquest of CA for security reasons, in Allworth's edited volume, she was stressing the economic reasons behind the conquest of the region:

${ }^{45} \mathrm{D}$ 'Encausse, Islam and the Russian Empire. 
The Crimean War at first had the effect of arresting Russian progress in Central Asia, but led, after its disastrous conclusions, to a renewal of interest in this region. For a while, at least, the czar had to give up the great foreign engagements which had involved him in the Balkans and the Near East, and he found it necessary to reinforce his position in Central Asia. For Russia, set on a course of capitalist development, the control of this region, with its unrivaled market and suspected rich raw materials, was of considerable importance. ${ }^{46}$

In her book Islam and the Russian Empire; Reform and Revolution in Central Asia that was written during the Cold War, d'Encausse's stress was on Soviet rule and its policies rather than the Tsarist regime. It is particularly because of that reason that perhaps she did not concentrated much on economic forces behind the conquest of the region; she preferred to identify the conquest simply with the 'security reasons'. Termination of East-West rivalry with the end of the Cold war, however, opened the road for further studies on the pre-Soviet regime and provided grounds for better analysis of the forces behind the Russian conquest of the region. Observing this change in the presentation of the initial encounter between the two societies will become much more crucial when we further analyze the presentation of other issues as well.

When she was explaining the post conquest environment, in terms of the administration of the region in the initial meeting, d'Encausse's words still carried a mild approach to the Russian conquest of the region: "in actual fact, Russian intervention in local institutions was then very limited. For a long time the local and the Russian hierarchies coexisted with very close ties". However, the flow of her words prepares the reader to a then changed situation. Her following words provides information on the changing attitude of the Russian regime and its influence on the Muslim population:

Any lowering of authority and decline of Russian prestige from this time forth in local opinion stemmed not, it would appear, from political or judicial limitations but quite simply from the scandals which marked the Von Kaufman period, and especially from the personality of his successors, who did not know how to assert themselves among the associates or over their subordinates. In the remote colony of Turkistan gubemiia each local Russian leader tended to behave as petty king whose power was not limited by any

${ }^{46}$ D'Encausse, Systematic Conquest, 1865 to 1884, p. 131. 
authority; this provoked frequent clashes with the Muslim population. ${ }^{47}$

Different from the works that came out during the Cold War, this time a cognizance of the negative aspects of the Tsarist regime on the Turkic identity building as well can be observed. It seems that she preferred to describe the initial Turkic resistance movements, which played an important role in the shaping of Turkic identity in the region, as 'frequent clashes' between the locals and the Russian authorities. However, while looking at the evolution of the Basmaci movement we have seen that those were more than mere clashes but initial moves of resistance to imperialism.

Furthermore, when we look at Mehrdad Haghayghi's book, titled Islam and Politics in Central Asia, which came out in 1995, the description of the pre-conquest $\mathrm{CA}$ and reasons given for the Russian conquest of the region were presented as follows:

The exploitative nature of tax and surplus expropriation on the one hand and the absence of well-defined borders among the three principalities on the other hand, left the majority of the peasant population destitute and the region in a semi-permanent state of conflict. Against this backdrop, Russia embarked upon the colonization of the whole of the Central Asia. The general strategy was motivated, above all by three broad objectives: political, economic and cultural. Much like other European colonial strategies of the nineteenth century, the czarist political aim was first to undermine the power of the traditional political authority at the highest level, though not dismantle it altogether, and second to extend its own political administrative authority, already in place elsewhere in the empire into that region. 48

Haghayghi's above lines reminds us the Orientalist justifications of the colonial and postcolonial stand of the West vis$\grave{a}$-vis the colonized countries. According to him the position of the Central Asian people was terrible before the conquest of the region and the Russian conquest was necessary to put and end to this

${ }^{47}$ Ibid., p. 156.

${ }^{48}$ Mehrdad Haghayghi, Islam and Politics in Central Asia, New York, St. Martin's Press, 1995, p. 3. 
negative conditions and bring civilization and modernization to these peoples. On the local resistance to the conquest, he obsorves:

Despite the widespread resentment, passive resistance and frequent rebellion, the Russian political reorganization of central Asia achieved its objectives: it divided the population along artificial lines, thus weakening the much cherished tribal cohesion, undermined the khan's political and financial authority, extended the coercive arm of the colonial government into the far reaches of the land and helped pave the way for further financial exploitation of the population. ${ }^{49}$

In the above lines author's acceptance of the existing resistance against the Russian policies in order to preserve the local identity by the Central Asian population can be observed. Moreover, there is also a stress on the exploitative character of the Russian presence in the region where it was not common to observe this sort of a definition of the Tsarist regime in the books that came out during the Cold War. Haghayghi defines the Central Asian behavior towards the Russian conquest and post-colonial policies as:

The Central Asian response to these developments generally followed two distinct patterns. The first was outright rebellion, which became an increasingly frequent method used against the Russian colonization after the Andijan uprising of 1898. The most serious incident of widespread rebellion occurred in 1916. Triggered by the czarist decree of June 25,1916 , that required labour services to the empire by the Muslim population, as well as by the misguided land policies in the Steppe, the rebellion engulfed almost the entire region leaving behind a large number of dead and wounded. The clerical establishment had played a leading role in this and many other rebellions and riots that swept through Turkistan. Although suppressed expeditiously, the rebellion clearly politicized the population and intensified the antiRussian sentiments. Nevertheless, the rebellion sent a clear signal to St. Petersburg as the volatility of the situation and the necessity to formulate the Central Asian policy: Islam had once again proven to be a potent anti-colonial instrument. ${ }^{50}$

It is important to note that Haghayghi, who is one of the post-Cold War writers of CA, realizes the importance of resistance movements during the Tsarist administration. From his above

${ }^{49}$ Ibid., p. 5.

50Ibid., pp. 9-10. 
words we can see that Islam, which is a significant aspect of the lives of local people, plays a vital role in the emergence of local resistance movements. Whereas these resistance, as he mentions as well, were the clear politicized demonstrations of the anti-Russian feelings and shaping of the Turkic identity in the region.

Nevertheless, like Cold War writers, he also has a conclusion at the end of his argument on the Tsarist regime and Islam which pushes the reader to have a bias vis- $d$-vis the comparison of the Tsarist administration versus Soviet administration of CA and its people:

Whether out of fear or negligence, the czarist cultural strategy did not include the wholesale destruction of the Islamic tradition. Instead, it aimed at projecting a positive image of the Russian culture, assuming that over the time "inferior" and archaic Islam would wither away. This policy, however, was to be radically challenged in the aftermath of the October Revolution of 1917 by the victorious Bolsheviks who believed that religion in general and Islam in particular would not wither away on its own, but must be dealt with swiftly and systematically if socialism was to succeed in Central Asia. ${ }^{51}$

Above lines provides us hints about the projected bias on the treatment of two administrations, both Tsarist and Soviet, towards the indigenous people. Where the first one was presented as designer of a set of policies that approached to the local people rather mildly, the latter presented as having violent approach toward the culture and Islamic identity of the local policies. In the post-Cold War writing on CA it is however, possible to observe a rather balanced treatment of the positions of the two administrations vis- $a$-vis the CA and its population compared to the Cold War writings. Although, it is possible to observe a rapprochement towards the Tsarist regime and its policies on CA, it is not yet possible to say that the Cold War trend totally eliminated.

In sum, it is possible to argue that it is not an easy task to keep political influences away from scholarship. Whenever they cut across, it is not easy to eliminate or change the created body of knowledge and adjust it to the new international political conditions.

${ }^{51}$ Ibid., p. 10 


\section{Post-Cold War Literature on the Turkic Identity under Soviet Regime: Group 4}

In this last section, the emphasis is on the analysis of the post-Cold War discourse and the presentation of the issue of Turkic identity under Soviet regime. As in the previous sections, a sample of literature chosen to show the trends in the post- Cold War era vis- $d$-vis the Soviet treatment of the Turkic population of CA.

When in 1917 the revolutionary winds were blowing in the Russian Empire, their effect on the Central Asian population carried importance in the determination of the position of the people vis-d-vis the new regime that came out as a result of this atmosphere. Although in February Revolution Central Asian population was not active, they were pretty much influenced by the changing conditions in the region. D'Encausse defines those revolutionary days as:

The February Revolution had been received with mix sentiments by the Central Asian population, giving the regime empowered there until the October revolution its specific character...They [Central Asian population] did not participate in the new events, for the scars of coercion still remained, but the downfall of a defeated power filled them with hope. ...Central Asians paid more attention to Muslim organizations [i.e. Muslim congresses] in which they thought their destiny was truly being manifested. ...The only point on which the Muslim delegates took a definite stand was that their destiny should not be unilaterally determined by Russia. ...For the first time since Central Asia became involved in nationalistic movements, local citizens really took in hand the destiny of the drive. ${ }^{52}$

Author stresses the mixed sentiments that Central Asians were feeling towards the February revolution. Those mixed sentiments were present because, on one hand there were indigenous desires for independence and on the other hand the past severe experiences of the 1916 revolt in the Fergana Valley. Above mentioned Muslim organizations were the 'All Muslim' congresses that was established in the region in order to cope with the unbalanced treatment of the local independence needs by the revolutionary leaders. However, because of the internal fragmentation within indigenous elite itself, it was not possible for

52D'Encausse, Systematic Conquest, 1865 to 1884, pp, 215-17. 
them to come together and act. When we look at Haghayghi's words on the reasons for local support to Bolsheviks, we can see how he explains the Bolshevik manipulation of the existing fragmentation between the Muslims of Russia to unite them to support the Bolshevik cause:

Lenin was fully aware of the significance of non-Russian nationalities in the battle for power, and as early as 1913 he had recognized the right of the nationalities to secede from Russia if they so desired... As a gesture of goodwill the Koran of Usman, which had been confiscated at the time of the Czarist conquest of Samarkand was returned to the Muslims. Such deliberate maneuvers were designed to galvanize the native Muslim population in favor of the revolution, but instead it further intensified the old aspirations for cultural independence and political autonomy, for which a number of congresses and Muslim organizations had been convened and established as early as $1905 . .^{53}$

In the above lines the stress is given on the successful manipulation of the independence desires of the Muslim population of the CA by the Bolshevik leader, Lenin. Moreover mentioning the Bolshevik gesture which is the returning of the 'Usman's Koran' is another demonstration by the author for the manipulation of the religious feelings of the indigenous people. In the beginning Bolsheviks seemed to supporting the independence cause of local Muslim people, however, his following word stresses the changing Bolshevik attitude towards Central Asian local identity and than developed attacks against the nationalist tendencies:

There is a very little doubt, however, that early 1918 , the Bolsheviks had reversed their liberal position on the nationalities question, and set out to dismantle all Muslim nationalist organizations in Turkistan, the Kazakh Steppe, and elsewhere. As a result, a military unit under the leadership of the Tashkent Soviet was dispatched, successfully defeating the Muslim resistance in Kokand, where the main antiSoviet clerical organization had moved to escape the persecution of the local Soviets. Until, November 1919, when the road to Tashkent was finally secured by the Red Army, leading to the resumption of the central command and communications to the region, the local Russians were left free to conduct antireligious campaigns during which mosques were profaned, clergy shot, religious endowment land

\footnotetext{
${ }^{53}$ Haghayghi, Islam and Politics in Central Asia, p. 16.
} 
confiscated, Shariah courts closed and religious schools were demolished. ${ }^{54}$

Haghayghi presents a short description of the harsh Bolshevik policies in the aftermath of the revolution. It is fascinating to observe that the same line of the Cold War followed here as well. In addition to Haghayghi's words, Yaacov Ro'i gives his explanation to this changing Bolshevik attitude, an explanation based on the undeniable role of Islam as the basic element of the indigenous Central Asian identity.

Islam like other religions, fell victim to the militant atheism that was an integral component of the materialist ideology of the Bolshevik party. Religion, 'the opium of the masses', was by definition an 'enemy of the people' par excellence. ...Pan-Islam and Pan-Turkism, if allowed to prosper, might bring together the otherwise diverse ethnic Muslim groups and enable them to withstand, and even break away from Russia, whose new rulers' authority had not yet been fully established. ${ }^{55}$

In the above lines Ro'i emphasized the Islam as threatening factor to the legitimacy of the regime. Because as a religion and as a way of life it had a strong place in the identification of local people themselves. In a region like CA, where the majority of people are Turks and Muslim, groupings based on Islamic identity were happened to be viewed by the Soviet rulers as a possible threat that may also trigger the ideas of pan-Turkism in the region. As a result of these threats to regime, the policies that were taken by the Soviet administration aimed the elimination of any sort of identification in the region.

It seems that Ro'i's stress of the anti-Islamic Soviet policies carries much of the character of a provocative strategy. A strategy that may engineer a sort of unity among the Turkic Muslim peoples of CA against the Soviet Union which once eliminated their chance for independence.

\footnotetext{
54Ibid., p. 17.

55Yaacov Ro'i (ed.), Muslim Euroasia; Conflicting Legacies, England, Frank Cass \& Co. Ltd., 1985, p. 5.
} 
While talking about the national delimitation policies that enhanced the impossibility of the establishment of unity in CA, Shirin Akiner was using the following words:

The National Delimitation, on paper at least, appeared to be a dramatic gesture of decolonisation. In reality it was the first step towards a far more radical form of colonization that had been practiced under Tsarist rule. It entailed a fundamental remodelling of Central Asian society, the avowed aim of which was the modernization and Sovietisation of the region... 56

Central Asian people who were bored of colonization and desperately looking for independence faced with another form of colonization by the Soviet regime. Although communism is not presenting a threat to the West anymore, above lines still continues in the same pattern to attack the communism and the communist regime. This is a clear evidence for the fact that if a body of knowledge created as a result of the international political conditions it was not that easy to change the flow of this knowledge when the international political conditions were not present anymore. Akiner's following words again seems to have an encouraging character for the Central Asian majority to come together and get united.

All other interpretations of history were banned. The break with the past was made even more complete by the changes of script, from the Arabic to Latin in 1930, from the Latin to the Cyrillic in 1940. The very languages themselves were reshaped, partly through emphasizing a selected dialectical base, partly through the addition of a considerable number of Russian/international terms. The only written sources of information that were available were those that, quite literally, had been sanctioned by the authorities. ${ }^{57}$

Since the alphabet and the history writing can be accepted as the important aspects of the self-identification of a nation, Soviet attitudes to eliminate these aspects were stressed. Above lines from Akiner proves an attack against Soviet administration and its policies vis- $d$-vis the treatment of nationalities in CA, where the majority are Turkic. The creation of artificial nationalities was

${ }^{56}$ Shirin Akiner, Central Asia: New Arc of Crisis?, London, Sherrens Printers, 1993, p.10.

${ }^{57}$ Ibid., p. 11. 
presented to be one of the 'divide and rule' policies that are developed by any colonial rule as well.

The new republics were given such trappings of independence as their own constitutions, flags and national anthems. They also had their own branches of the Communist Party, the Communist Youth League (Komsomol) and the trade unions. However, the reality behind the facade was that the republics were entirely subservient to the centre... Central Asians today describe this experience with anguish as "a loss of memory". This is no exaggeration. The enforced westernization and Sovietization of society very nearly succeeded in obliterating traditional spiritual and cultural values. ${ }^{58}$

Akiner presented new republics of CA as artificial outcomes of the Soviet policies, which does not posses the main essential component of a state that is the nation. According to the author, Soviet-created nations of Uzbek, Kyrgyz, or Tajik can not be regarded as pure nationalities. Rather they were different sects of a larger nation that is the Turkic Muslim people of CA, which for more than seventy years tried to be eliminated by the Soviet regime. Akiner defines this period as a 'loss of memory' for more than seventy years, where she stress that it is not an exaggeration. But what is going to be the situation now since the elements that are causing for the memory loss were softened or almost eliminated? This is still left as an open-ended question!

\section{Concluding Remarks}

No one has ever devised a method for detaching the scholar from the circumstances of life, from the fact of his/her involvement (conscious or unconscious) with a class, a set of beliefs, a social position, or from the mere activity of being a member of a society. These continue to bear on what $\mathrm{s} /$ he does professionally, even though naturally his/her research and its fruits do attempt to reach a level of relative freedom from the inhibitions and the restrictions of brute, everyday reality. For there is such a thing as knowledge that is less, rather than more, partial than the individual (with his/her entangling and distracting circumstances) who produces it. Yet this knowledge is not therefore automatically nonpolitical. ${ }^{59}$

58 Ibid., pp. 13 and 17.

${ }^{59}$ Said, Orientalism, p. 10. 
Edward Said was defining orientalism "... as a Western style for dominating, restructuring, and having authority over the Orient". 60 Starting from his definition of Orientalism and Orientalist discourse as a tool of power for achievement of control and authority, this article tends to define the Western scholarly discourse on Turkic identity as one of the tools for the containment of the East, that is the Soviet Union. Starting from this definition, a comparison of the Said's perception of the Orientalist discourse with our perception of the Western scholarly discourse on Turkic identity is provided below:

1) While Said was providing his 'reasonable qualifications' for the study of orientalism, he was saying that "... it would be wrong to conclude that the Orient was essentially an idea, or creation with no corresponding reality". This statement is valid if we apply it to the issue of Turkic identity in CA. It would be wrong if one argues that the issue of Turkic identity and treatment of nationalities by the Soviet administration was totally exaggerated. However, the important side of the analysis of the discourse on the Turkic identity for this study was to see how the presentation of the issue shifted depending on the international political conditions. While the Tsarist administration and its treatment of nationalities were presented as a rather mild process Soviet policies were stressed and criticized.

2) The above argument becomes clearer when we look at his second 'qualification' for the study of orientalism. He was arguing that:

...ideas, cultures, and histories cannot seriously be understood or studied without their force, or more precisely their configurations of power, also being studied. To believe that the Orient was createdor as I call it, "Orientalized" and to believe that such things happen simply as a necessity of the imagination, is to be disingenuous. The relationship between Occident and Orient is a relationship of power, of domination, of varying degrees of a complex hegemony... The Orient was Orientalized, not only it was discovered to be "Oriental" in all those ways considered commonplace by an average nineteenth-century

${ }^{60}$ Ibid., p. 3. 
European, but also because it could be that is, submitted to being made Oriental. ${ }^{61}$

Said's above analysis of creation of the Orientalist discourse on Arabs provides means for us to argue that accepting the creation of a body of knowledge on the Turkic identity in CA by the Western scholars as merely because of intellectual curiosity is to be 'disingenuous'. It is necessary to understand the historical and political power structures of the era that they came out. Bearing in mind the Cold War political conditions and the rivalry between the East and the West, it is natural to observe the reflections of life on scholarship as well.

3) Said's third 'qualification' for the study of orientalism are as follows:

Orientalism, therefore, is not an airy European fantasy about the Orient, but a created body of theory and practice in which, for many generations, there has been a considerable material investment. Continued investment made Orientalism, as a system of knowledge about the Orient, an accepted grid for filtering through the Orient into Western consciousness, just as that same investment multiplied indeed, made truly productivethe statements proliferating out from Orientalism into the general culture. ${ }^{62}$

Just as the creation of an Orientalist body of knowledge which in practice stays for generations and still carries its power, the discourse on Turkic identity as well stays as a body of knowledge still carrying the signs of Cold-War rivalry between the East and the West. Although the Cold-War ended, it is not possible to eliminate what have been produced and start again, as it will be wrong to totally disregard what has been produced.

${ }^{61}$ Ibid., p. 6.

${ }^{62}$ Ibid., p. 6. 